\title{
Heavy metals accumulation in Hertia cheirifolia along the highway in Setif region, Algeria
}

\author{
AMINA BELGUIDOUM, TAKIA LOGRADA, MESSAOUD RAMDANI" \\ Laboratory for Valorization of Natural Biological Resources, SNV Faculty, Ferhat Abbas University Setif-1. El Bez, Sétif 19000, Algeria. \\ Tel.: +213-658-101010, `email: ramdanimessaoud@yahoo.com
}

Manuscript received: 19 April 2020. Revision accepted: 26 May 2020.

\begin{abstract}
Belguidoum A, Lograda T, Ramdani M. 2020. Heavy metals accumulation in Hertia cheirifolia along the highway in Setif region, Algeria. Biodiversitas 21: 2786-2793. The aim of this work was to study the possibility of using Hertia cheirifoia spontaneous plant, generally present in uncultivated environments, as an indicator of pollution. The aerial parts of ten $H$. cheirifolia populations were collected along the East-West highway. Sampling is carried out in areas considered polluted or low contaminated in the region of Setif. Nine metallic trace elements concentrations ( $\mathrm{Pb}, \mathrm{Zn}, \mathrm{Cu}, \mathrm{Fe}, \mathrm{Mn}, \mathrm{Cd}, \mathrm{Ag}, \mathrm{Bi}$, and $\mathrm{Sb}$ ) were determined, for each population, by Atomic Absorption Spectrophotometry with Flame (AASF). Statistical analyzes were performed using mainly box and whisker diagrams, principal component analysis, and UPGMA. The concentrations detected for contaminants (MTE), in general, were very high, far exceeding international certified standards. The MTE concentrations in different populations were calculated for each metal and a positive correlation is observed. The order of MTE in the plant was found as follows: $\mathrm{Fe}>\mathrm{Zn}>\mathrm{Mn}>\mathrm{Pb}>\mathrm{Sb}>\mathrm{Cu}>\mathrm{Bi}>\mathrm{Ag}>\mathrm{Cd}$. The Fe concentrations are very high in $H$. cheirifolia with an average of $3600 \pm 1491.5 \mathrm{mg} / \mathrm{kg}$. The populations of $H$. cheirifolia have shown a significant capacity to accumulate heavy metals. The presence of metal ions in the aerial parts of the plant designates that $H$. cheirifolia is a super accumulator of MTE and can be used as a bioindicator, which opens up prospects for its application to soils phytoremediation.
\end{abstract}

Keywords: Algeria, bioaccumulation, bioindication, heavy metal, Hertia cheirifolia, Setif

\section{INTRODUCTION}

The term metallic trace elements (MTE), is assimilated to the term "heavy metals", designates metals and metalloids often reputed to be toxic, present in low dose environments (Connelly 2005; Rollin and Quiot 2006; Hasanuzzaman et al. 2018). The accumulation of heavy metals, natural components of the environment, is worrying. This occurrence is attributed to rapid population growth, urbanization, and the expansion of industrial activities (Aksoy et al. 2000; Simmons et al. 2003; Aslam et al. 2012; Tossapol et al. 2015).

The presence of MTE in the soil is not indicative of pollution (Baize 2000), because the rates of MTE in the soil depend on the rock of origin (Dung et al. 2013). Road transport contaminates the atmosphere, water, and soil near highways by atmospheric fallout. Traffic pollutants include potentially toxic metals (Caussy et al. 2003; Akbar et al. 2006; Olukanniand and Adebiyi 2012). Many studies have shown contamination by these elements, near highways (Turer and Maynard 2003; Atayese et al. 2010). Plants are the basis of the food chain and can absorb MTE ground by biosorption or bioaccumulation (Atayese et al. 2010). The levels of heavy metals in roadside plants vary by species, so-called hyper-accumulating plants. These plants are able to accumulate high levels of MTE at concentrations 10 to 100 times the value tolerated by most plants (Krämer and Chardonnens 2001; Gratao et al. 2005; Gav et al. 2015).
Plants are used in bioindication; it is a low-cost process to assess the degree of pollution (Rucandio et al. 2011). Hertia cheirifolia species is considered a heavy metal accumulator and has a potential for phytoremediation of metallic trace elements (Lograda et al. 2016). The aims of the work are the study the bioaccumulation potential of MTE by Hertia cheirifolia, collected on the along a highway, and to identify its potential for phytoremediation.

\section{MATERIALS AND METHODS}

\section{Study area}

Ten stations, located at Setif region, Algeria (Table 1), were selected for the sampling of the species Hertia cheirifolia (Figure 1). The climate of the study area is semi-arid, cold in winter and hot in summer. The average annual rainfall is $322 \mathrm{~mm}$ and rarely exceeds $500 \mathrm{~mm}$ and the annual average temperature is $15^{\circ} \mathrm{C}$.

\section{Selection of the plant}

Hertia cheirifolia, synonymous with Othonnopsis cheirifolia, is a species with very original leaves, persistent, gray, thick, forming a dense ground cover. In spring, the flowering is bright yellow. This species is native to Algeria and Tunisia. The selection of $H$. cheirifolia is based on a previous study on the bioaccumulation of heavy metals in this species (Lograda et al. 2016). It is a very popular plant in the region. The samples were transported to the laboratory in paper bags. 

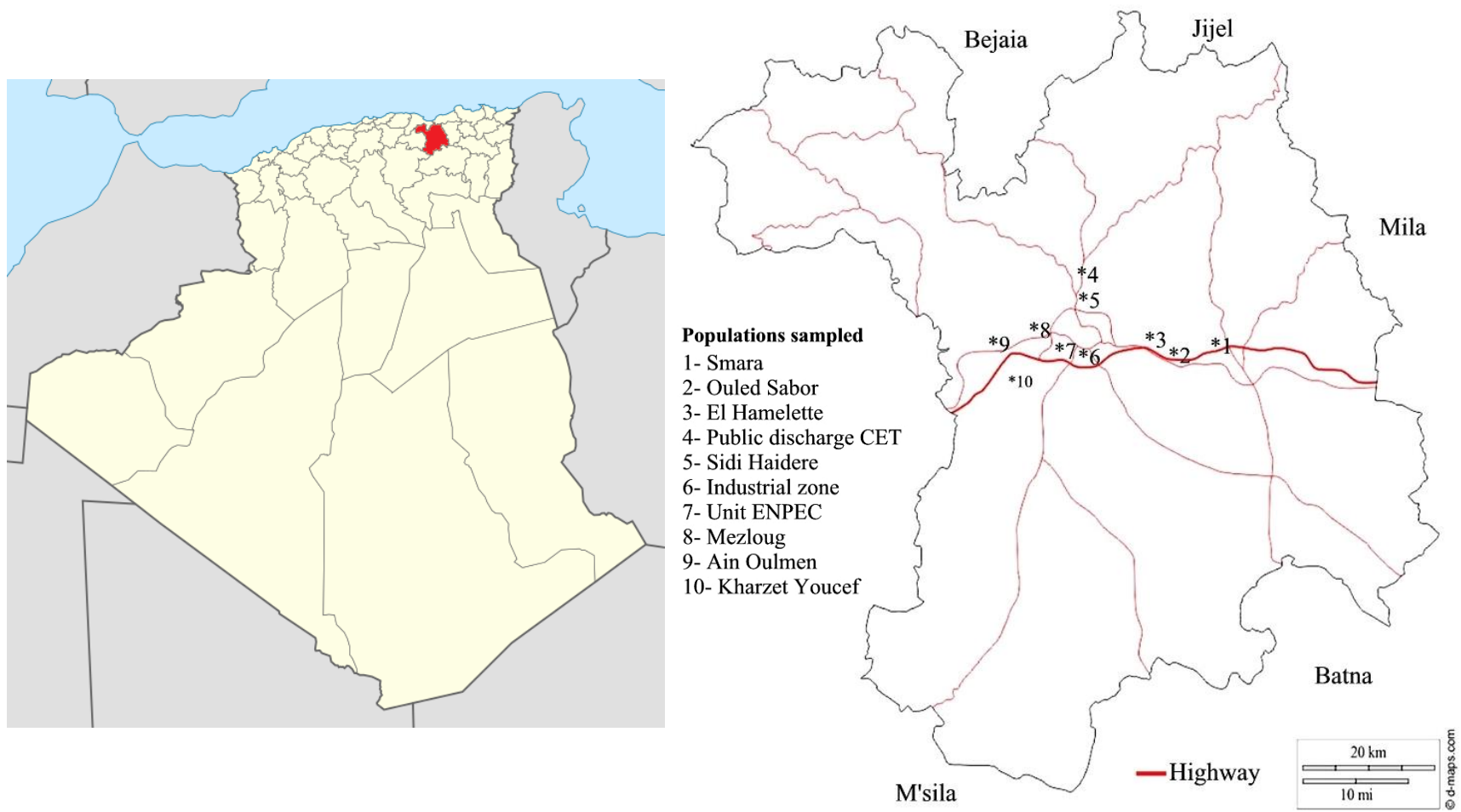

Figure 1. Hertia cheirifolia populations sampled along the highway in Setif region, Algeria

Table 1. Geographical coordinates of sampled stations

\begin{tabular}{clrrr}
\hline No. & \multicolumn{1}{c}{ Stations } & \multicolumn{2}{c}{ Geographic coordinates } & $\begin{array}{r}\text { Altitude } \\
\text { (m asl) }\end{array}$ \\
\hline 1 & Smara & $36^{\circ} 09^{\prime} 47.2^{\prime \prime N}$ & $5^{\circ} 36^{\prime} 54.1^{\prime \prime} \mathrm{E}$ & 1000 \\
2 & Ouled Sabor & $36^{\circ} 10^{\prime} 30.3^{\prime \prime} \mathrm{N}$ & $5^{\circ} 30^{\prime} 45.3^{\prime \prime} \mathrm{E}$ & 1100 \\
3 & El Hamelette & $36^{\circ} 09^{\prime} 32.2^{\prime \prime N}$ & $5^{\circ} 33^{\prime} 24.5^{\prime \prime} \mathrm{E}$ & 1150 \\
4 & Public Discharge CET & $36^{\circ} 14^{\prime} 13.3^{\prime \prime} \mathrm{N}$ & $5^{\circ} 28^{\prime} 58.9^{\prime \prime} \mathrm{E}$ & 1130 \\
5 & Sidi Haider & $36^{\circ} 13^{\prime} 23.1^{\prime \prime} \mathrm{N}$ & $5^{\circ} 27^{\prime} 44.1^{\prime \prime} \mathrm{E}$ & 1150 \\
6 & Industrial zone & $36^{\circ} 09^{\prime} 35.3^{\prime \prime} \mathrm{N}$ & $5^{\circ} 25^{\prime} 08.4^{\prime \prime} \mathrm{E}$ & 1000 \\
7 & Unit ENPEC & $36^{\circ} 09^{\prime} 54.5^{\prime \prime} \mathrm{N}$ & $5^{\circ} 25^{\prime} 10.6^{\prime \prime} \mathrm{E}$ & 1000 \\
8 & Mezloug & $36^{\circ} 05^{\prime} 41.7^{\prime \prime} \mathrm{N}$ & $5^{\circ} 20^{\prime} 23.4^{\prime \prime} \mathrm{E}$ & 1050 \\
9 & Ain Oulmen & $35^{\circ} 56^{\prime} 40.0^{\prime \prime} \mathrm{N}$ & $5^{\circ} 17^{\prime} 48.3^{\prime \prime} \mathrm{E}$ & 950 \\
10 & Kharzet Youcef & $35^{\circ} 50^{\prime} 28.2^{\prime \prime} \mathrm{N}$ & $5^{\circ} 27^{\prime} 45.5^{\prime \prime} \mathrm{E}$ & 900 \\
\hline
\end{tabular}

\section{Samples preparation}

\section{Cleaning and grinding}

It consists of eliminating any atmospheric deposit. After measuring the fresh weight, samples of $400 \mathrm{~g}$ of plants were dried at $80{ }^{\circ} \mathrm{C}$ for $48 \mathrm{~h}$, and then the dry weight was measured, crushed, and sieved through a nylon sieve to obtain a fine powder.

\section{Mineralization}

The method of Tauzin and Just (Adjiri et al. 2018) was used. It consists in calcining 1 to $2 \mathrm{~g}$ (stems, leaves, and roots crushed) in a muffle furnace at $450^{\circ} \mathrm{C}$ for four hours. The ash thus obtained are mineralized by aqua regia $\left(25 \% \mathrm{HNO}_{3}\right.$ and $\left.75 \% \mathrm{HCl}\right)$, then reduced to dry until discoloration of the mineral deposit occurs, on a sand bath. The residue is dissolved in $10 \mathrm{ml} \mathrm{HCl} 5 \%$. Then filtered on Whatman, paper with $0,45 \mu \mathrm{m}$ of diameter, and completed to $20 \mathrm{ml}$ with $\mathrm{HCl} 5 \%$. Heavy metals were assayed by Atomic Absorption Spectrophotometer with Flame
(AASF) in the laboratory of Valorization of Natural Biological Resources, Setif University.

\section{Analytical procedures for MTE concentrations}

The concentrations of the following elements $(\mathrm{Pb}, \mathrm{Zn}$, $\mathrm{Cu}, \mathrm{Fe}, \mathrm{Mn}, \mathrm{Cd}, \mathrm{Ag}, \mathrm{Bi}$, and $\mathrm{Sb}$ ), were determined by Atomic Absorption Spectrophotometry, with Flame (AASF). There are no established standards of trace elements concentration in ppm. To interpret the results of each element studied, we use as standard reference values, the unit's concentration ranges. The obtained results in $(\mathrm{g} / \mathrm{l})$ are transformed into $\mathrm{mg} / \mathrm{kg}$ using the following relationship:

$$
T\left(\frac{m g}{\mathrm{~kg}}\right)=\mathrm{C} \frac{\mathrm{V}}{\mathrm{s}}
$$

Where; $\mathrm{T}$ : element concentration in $\mathrm{mg} / \mathrm{kg} ; \mathrm{C}$ : concentration of the element in $\mathrm{mg} / \mathrm{l}$ determined by the calibration curve; $\mathrm{V}$ : extraction volume in $\mathrm{ml}$ and $\mathrm{S}$ : sample weight in grams

\section{Statistical analysis}

Data were first subjected to Principal Components Analysis (PCA) to examine the relationships among the trace elements and the bioaccumulation by this plant and the relationships between the presence of these elements and the vehicle circulations. Cluster analysis, Un-weighted pair group method with arithmetic mean (UPGMA), was carried out on the original variables and on the Manhattan distance matrix to seek for hierarchical associations among the elements and stations. The statistical analyses were carried out using STATISTICA 10 software. 


\section{RESULTS AND DISCUSSION}

\section{Results}

After selecting the sites of studies; the aerial parts of Hertia cheirifolia were collected and subjected to analysis of heavy metals by AASF. This analysis revealed the presence of high rates of MTE in this species (Table 2).

All elements quantified in Hertia cheirifolia populations far exceed the standard values. The concentrations detected for contaminants (MTE), in general, were very high, far exceeding international certified standards values (Figure 2). The concentration of MTE in the different populations was calculated for each metal and a positive correlation is observed. The order of MTE in the plant was found as follows: $\mathrm{Fe}>\mathrm{Zn}>\mathrm{Mn}>\mathrm{Pb}$ $>\mathrm{Sb}>\mathrm{Cu}>\mathrm{Bi}>\mathrm{Ag}>\mathrm{Cd}$.

The cluster analysis clearly shows the presence of two clades (Figure 3). The element Fe, present in populations with very high concentrations with an average of (3600 \pm $1491.5 \mathrm{mg} / \mathrm{kg}$ ), forms the first clade. In the second clade, $\mathrm{Zn}$ forms a subgroup and isolates itself from the rest of the elements with an average concentration of $(1000 \pm 434.6$ $\mathrm{mg} / \mathrm{kg}$ ), followed by $\mathrm{Mn}$ and $\mathrm{Pb}$. The UPGMA confirms the correlation that exists between the concentrations of MTE in the different populations.

The concentrations of $\mathrm{Zn}, \mathrm{Pb}, \mathrm{Fe}$, and $\mathrm{Mn}$, in $H$. cheirifolia, are highly variable (Figure 4). Iron is very high in all stations with rates exceeding the standard value. The samples of Kharzet Youcef (pushing on the floor of the mine) and the Public discharge CET reveal a presence of high levels of $\mathrm{Zn}$ and $\mathrm{Mn}$ elements, far exceeding international standards.

$\mathrm{Cd}$ and $\mathrm{Ag}$ although their concentrations exceed the standard values, their concentrations in $H$. cheirifolia are low compared to the other elements like $\mathrm{Sb}, \mathrm{Cu}$, and $\mathrm{Bi}$ (Figure 5).

Hertia cheirifolia populations show very high differences in the concentrations of the MTE. To compare profiles with Elements trace metallic we considered each
MTE as a quantitative variable. The spatial threedimensional projection of the 10 populations based on the three main axes from the PCA (Figure 6), shows that the populations of Kharzet Youcef, Unit ENPEC and Public discharge CET are distinctly separated, but the others populations studied are not clearly distinguished and their separation into homogeneous groups is less clear.

The UPGMA clusters analysis based on the linkage distance confirms the results of the PCA and separates $H$. cheirifolia populations in two distinct clades (Figure 7). These populations' clustration in small groups indicates differences in the MTE concentrations. The first cluster regroups Ain Oulmen and Kharzet Youcef populations, who are characterized by a high content of $\mathrm{Fe}, \mathrm{Zn}$, and $\mathrm{Mn}$, these two stations are located near a Zinc mine.

The second cluster is composed of three subgroups: The unit of ENPEC and the Public discharge CET are characterized by a high level of $\mathrm{Fe}, \mathrm{Pb}, \mathrm{Zn}, \mathrm{Mn}, \mathrm{Sb}$, and $\mathrm{Bi}$. The second subgroup includes the populations of Ouled Sabor, Sidi Haidere, Industrial Zone, Elhamelette, Smara, and Mezloud; those populations are characterized by a high level of $\mathrm{Fe}, \mathrm{Zn}, \mathrm{Sb}$, and $\mathrm{Bi}$.

\section{Discussion}

The populations of Hertia cheirifolia analyzed showed variable MTE accumulation responses in the different stations. For most elements, studied concentrations are high, in particular for $\mathrm{Fe}, \mathrm{Zn}, \mathrm{Mn}, \mathrm{Pb}$, and $\mathrm{Sb}$. These elements are, generally considered to be mainly of anthropogenic origin (Adimalla and Wang 2018; Djeddi et al. 2018; Adimalla et al. 2019; Saljnikov et al. 2019; Sun et al. 2019). The high sample contamination has many origins, including, the mining activity of Kharzet Youcef, Industrial Zone, Unit ENPEC (manufacture of Batteries), Technical landfill center, Sidi Haidere (Scrap depot) and the vehicle traffic, which can transmit this contamination to the food chain (Ben Ghaya et al. 2013).

Table 2. Accumulation of metallic trace elements by Hertia cheirifolia

\begin{tabular}{|c|c|c|c|c|c|c|c|c|c|}
\hline Stations & $\mathbf{P b}$ & $\mathbf{Z n}$ & $\mathbf{C u}$ & $\mathbf{F e}$ & Mn & Cd & Ag & $\mathbf{B i}$ & $\mathbf{S b}$ \\
\hline Ouled Sabor & 68 & 800 & 70 & 3800 & 230 & 7 & 8 & 71 & 170 \\
\hline El Hamelette & 21 & 800 & 89 & 2700 & 200 & 6 & 6 & 60 & 120 \\
\hline Smara & 90 & 700 & 100 & 2400 & 530 & 7 & 7 & 62 & 160 \\
\hline Sidi Haidere & 45 & 900 & 150 & 3100 & 310 & 11 & 9 & 62 & 170 \\
\hline Public discharge CET & 175 & 1800 & 124 & 3300 & 260 & 11 & 9 & 64 & 190 \\
\hline Industrial zone & 71 & 800 & 92 & 3300 & 460 & 9 & 11 & 66 & 70 \\
\hline Unit ENPEC & 1100 & 1000 & 111 & 2300 & 420 & 8 & 10 & 65 & 170 \\
\hline Mezloug & 27 & 600 & 96 & 2700 & 580 & 6 & 10 & 50 & 150 \\
\hline Ain Oulmen & 26 & 800 & 73 & 5400 & 380 & 5 & 8 & 52 & 100 \\
\hline Kharzet Youcef & 44 & 1800 & 62 & 7000 & 300 & 15 & 10 & 37 & 90 \\
\hline Average & 166.7 & 1000 & 96.7 & 3600 & 367 & 8.5 & 8.8 & 58.9 & 139 \\
\hline Min. & 21 & 600 & 62 & 2300 & 200 & 5 & 6 & 37 & 70 \\
\hline Max. & 1100 & 1800 & 150 & 7000 & 580 & 15 & 11 & 71 & 190 \\
\hline SD & 331 & 434.6 & 26.6 & 1491.5 & 128.9 & 3.1 & 1.6 & 9.9 & 41 \\
\hline RSD & 198.56 & 43.46 & 27.5 & 41.43 & 35.12 & 36.47 & 18.18 & 16.8 & 29.49 \\
\hline Standard value & 1 & 50 & 10 & 150 & 200 & 0.05 & 0.2 & 0.06 & 0.1 \\
\hline
\end{tabular}




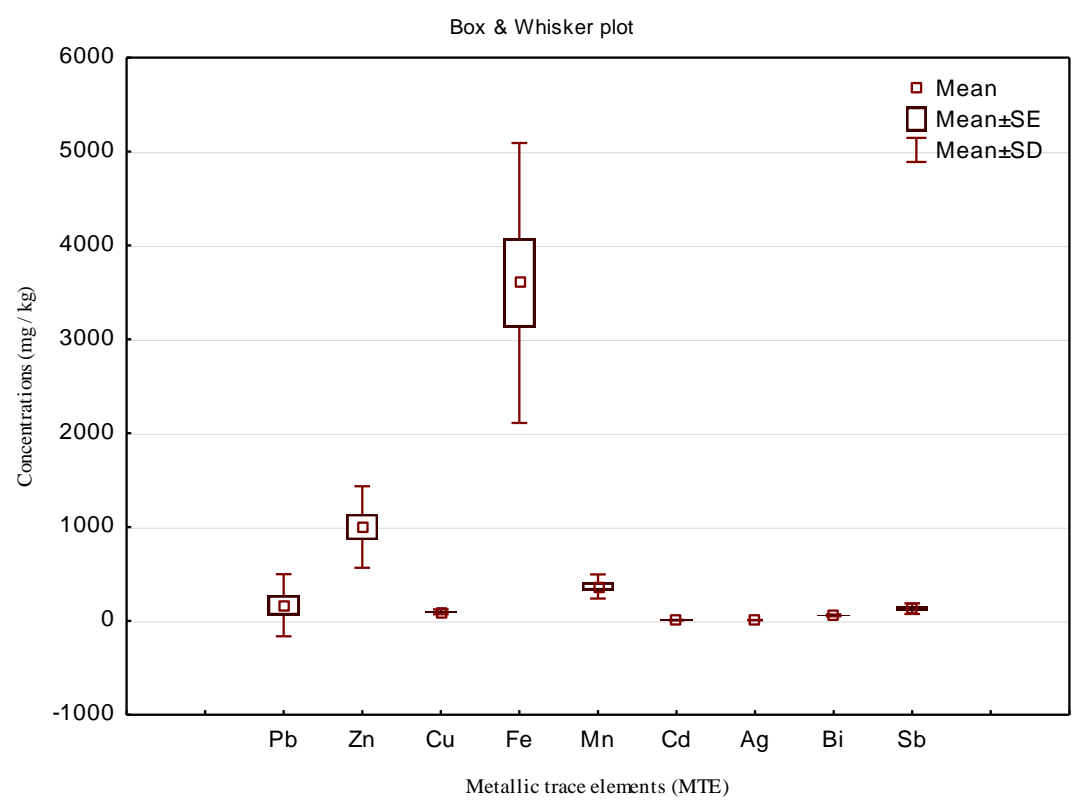

Figure 2. Variation in MTE concentrations in Hertia cheirifolia

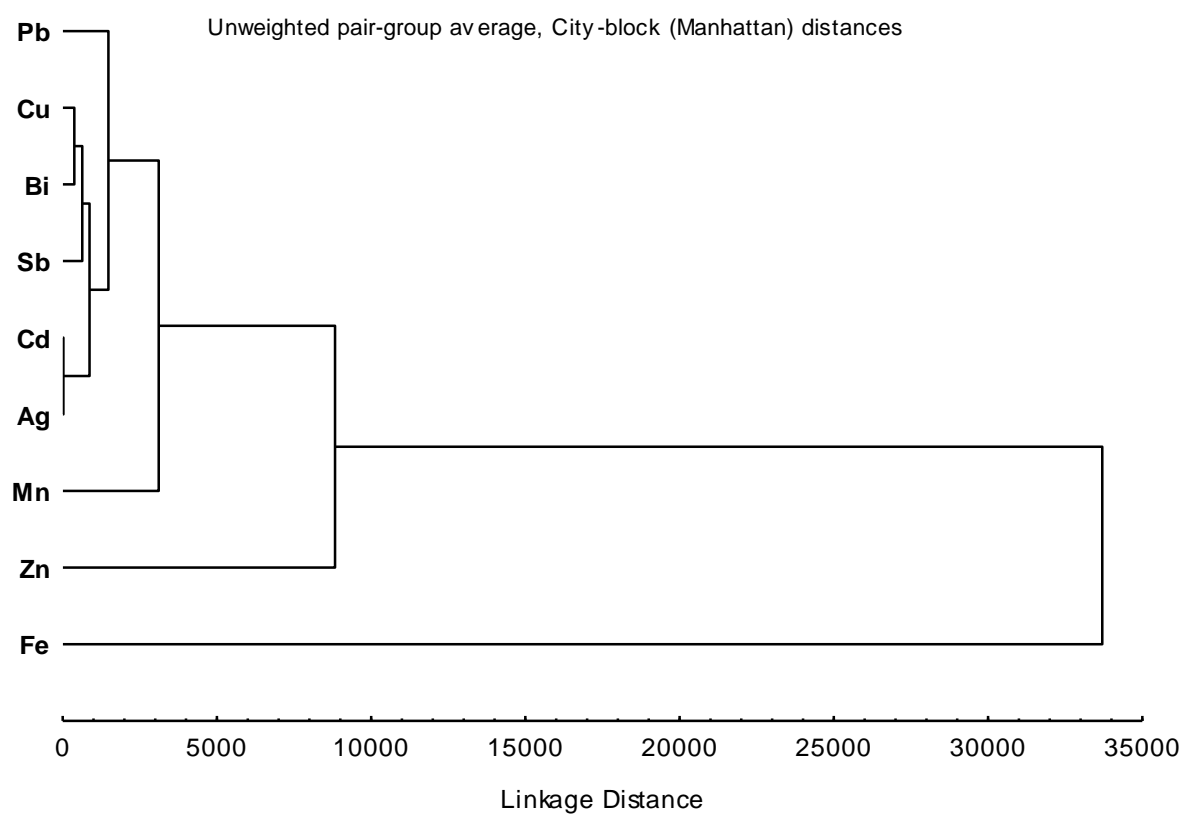

Figure 3. Correlation of concentration heavy metals in Hertia cheirifolia

The concentrations of $\mathrm{Pb}, \mathrm{Cu}, \mathrm{Zn}, \mathrm{Mn}, \mathrm{Cd}$, and $\mathrm{Fe}$ are very high in most samples of $H$. cheirifolia and exceed the standards values, according to Cheng (2003) species with this characteristic can be used in bioindication to monitor soil and area contamination. $H$. cheirifolia can be used in the phytoextraction of MTE, based on the use of potential hyper-accumulation to extract the MTE from the soil and transfer them to the aerial parts (Kambhampati et al. 2003; Gardea-Torresdey et al. 2005; Mnasri et al. 2015).
The average Iron concentration exceeds the standard value in the $H$. cheirifolia plant; this high rate is due to the genetic and physiological capacity of the plant to accumulate this element. $\mathrm{Fe}$ is an element of the soil that undergoes significant bioaccumulation in plants that produce chelators (Marrassini et al. 2018). The high values for $\mathrm{Zn}$ and $\mathrm{Pb}$ in $H$. cheirifolia exceed certified standards. These concentrations are closely linked to emissions from heavy traffic (Francová et al. 2017; Bentum et al. 2018; Hassan 2018; Adimalla et al. 2019; Kumar et al. 2019). 
The Unit ENPEC Station, which is well known by this electrochemical product and waste of heavy metals, recorded very high value of $\mathrm{Pb}$, this element, can pollute the surrounding soil through releases and atmospheric deposits (Zhang et al. 2015; Dron et al. 2016). Similar studies were carried out in the mining regions, and the same conclusions were issued ( $\mathrm{Wu}$ et al. 2020). The concentrations of $\mathrm{Zn}, \mathrm{Fe}$, and $\mathrm{Cd}$ exceed regulatory levels in the region of Kharzet Youcef, which is associated with mining. Similar contamination has been reported in similar areas (Lograda et al. 2016; Drahota et al. 2018; Hesami et al. 2018).

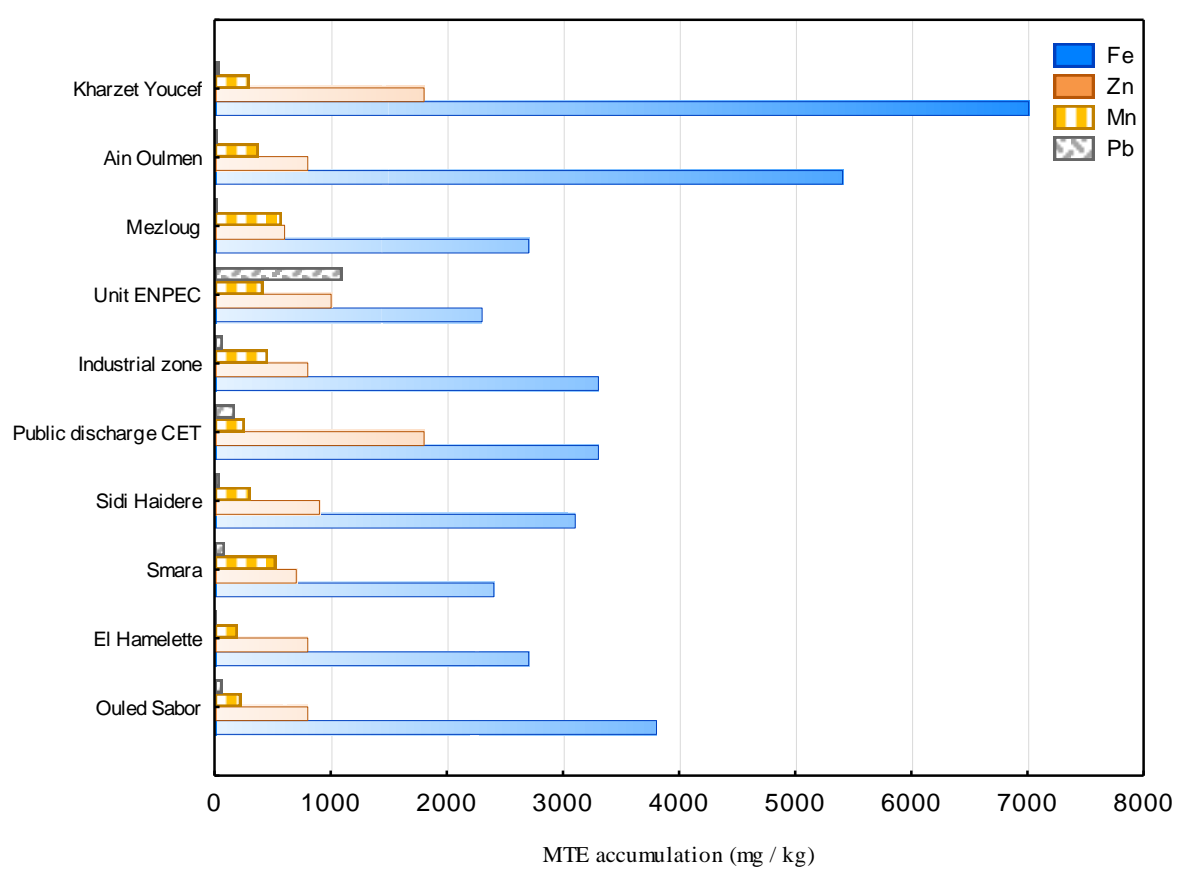

Figure 4. Concentration of $\mathrm{Fe}, \mathrm{Zn}, \mathrm{Mn}$, and $\mathrm{Pb}$ in Hertia cheirifolia

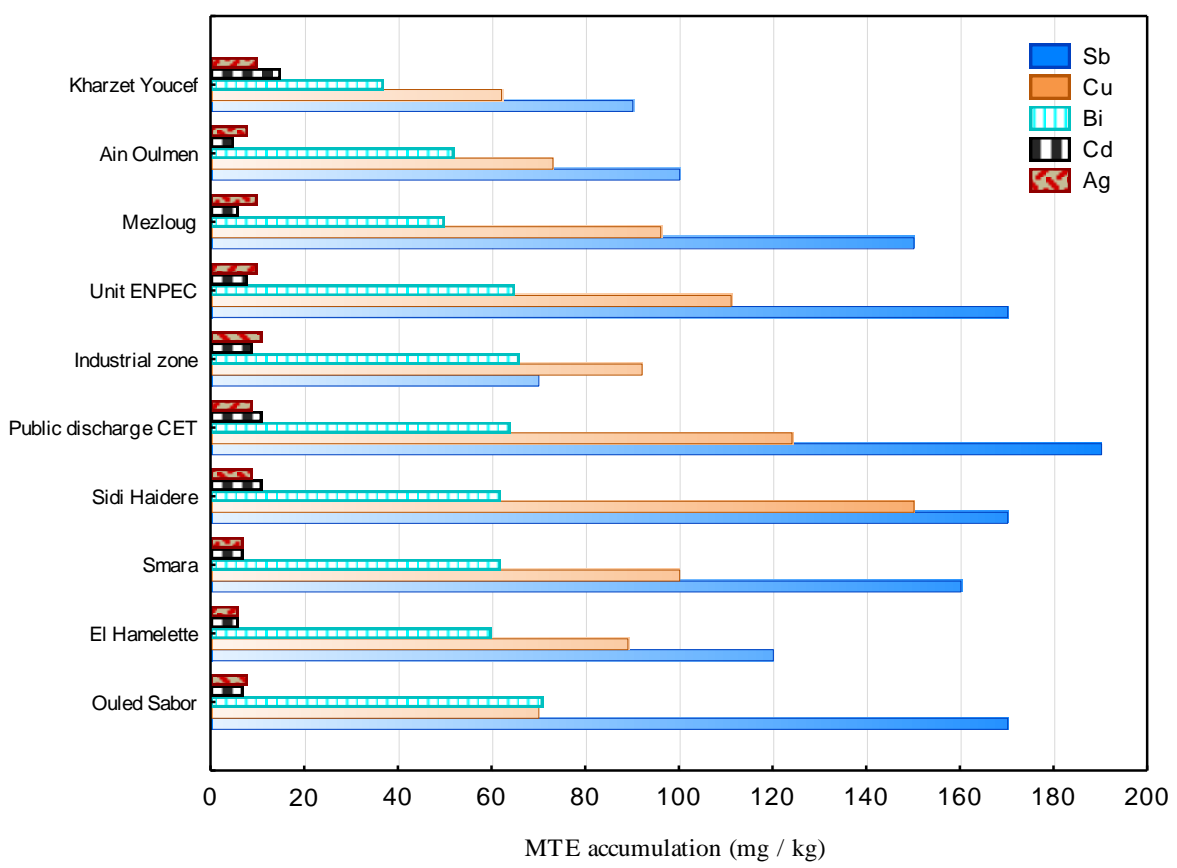

Figure 5. Concentration of $\mathrm{Sb}, \mathrm{Cu}, \mathrm{Bi}, \mathrm{Cd}$, and $\mathrm{Ag}$ in Hertia cheirifolia 


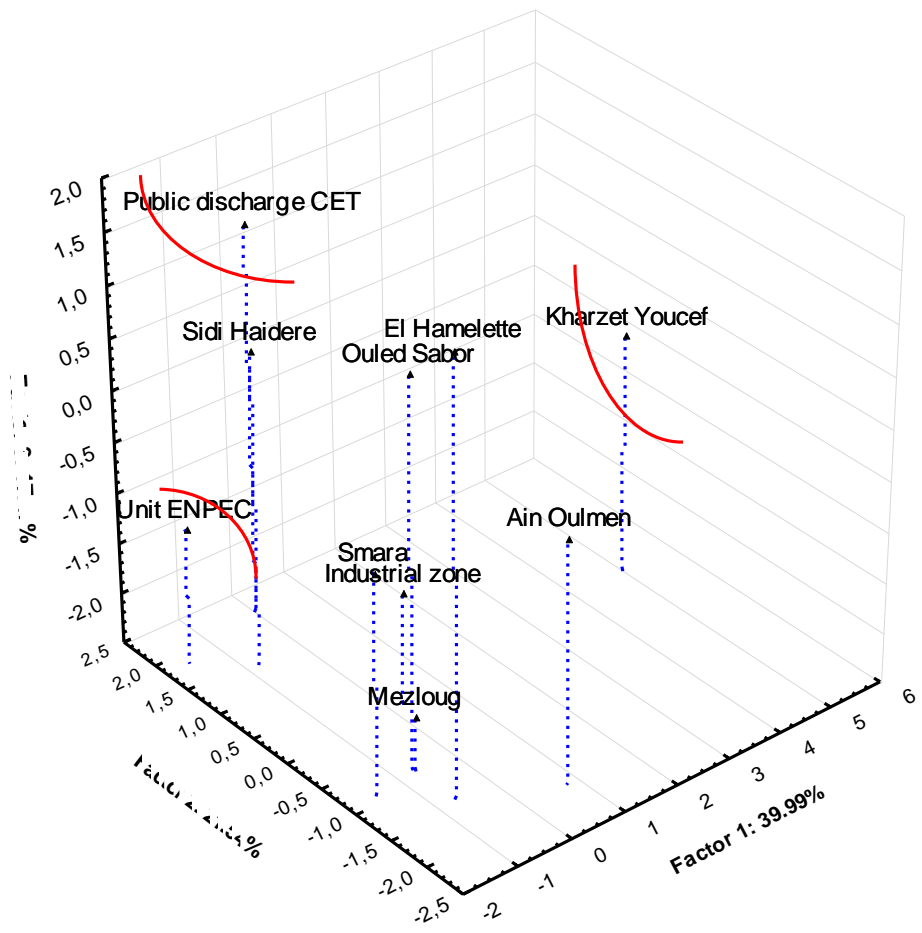

Figure 6. Three-dimensional spatial projection of Hertia cheirifolia populations

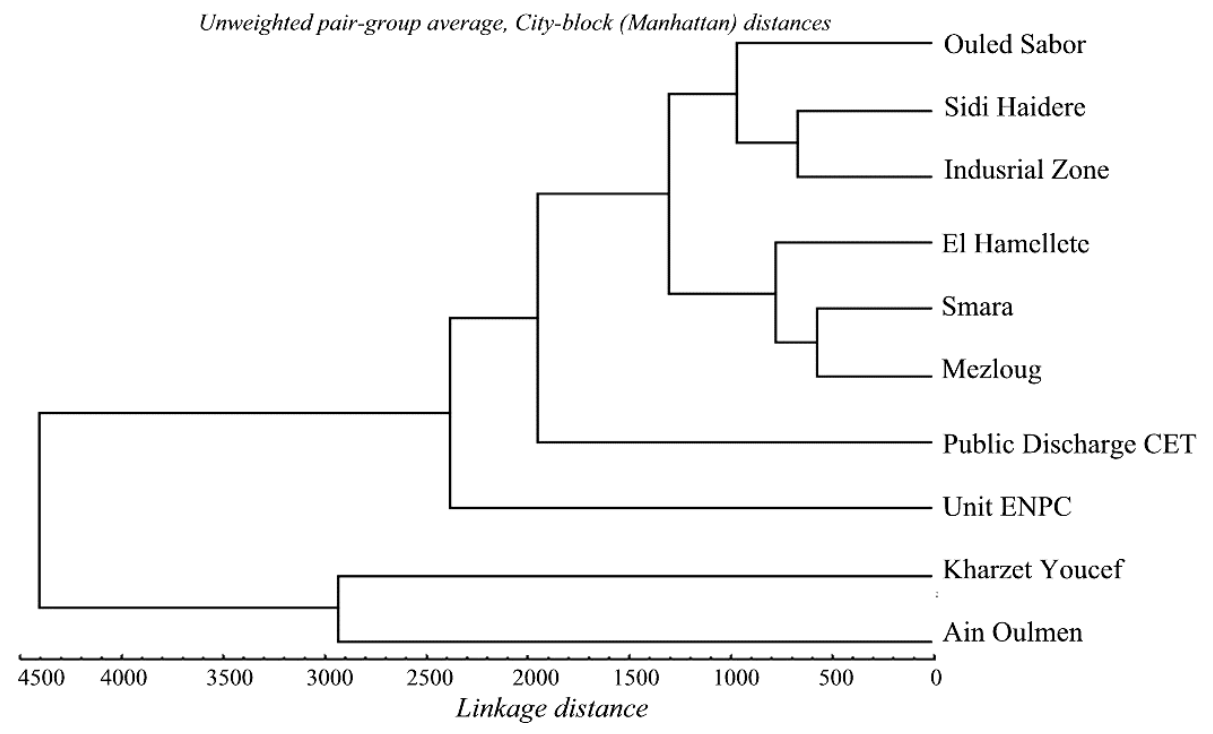

Figure 7. UPGMA, based on the concentration of heavy metals

The bismuth concentrations are very high, if we compare them with the $\mathrm{Pb}$ distribution rate, we notice similar values between the stations most contaminated by the two elements (Unit ENPEC, Public discharge CET and Industrial zone). $\mathrm{Bi}$ is often a sub-product of lead mining, so most industrial releases containing $\mathrm{Pb}$ imply the presence of traces of bismuth (Tighe et al. 2019). However, the highest concentration of $\mathrm{Bi}$ is recorded in the Ouled Saber station, this concentration is probably due to the agricultural activity that characterizes the region; the application of fertilizers produces relatively high concentrations of Bismuth (Kabata-Pendias et al. 2007). The concentration of $\mathrm{Sb}$ is high in most of the stations studied; this is mainly due to road traffic, ash from the waste, which burns especially in summer (Bisson et al. 2007), industrial activity, and road traffic (Negral et al. 2020).

The high concentrations of MTE found in the uncontrolled open landfill site have several origins. The high levels of $\mathrm{Zn}, \mathrm{Sb}$, and $\mathrm{Pb}$ are the consequence of the 
presence of leachate, which contains many mineral contaminants (Baziene et al. 2020). Authors made the same observations confirming that the leachate is highly polluted by MTE, with major contamination by $\mathrm{Zn}$ and $\mathrm{Pb}$ (Koné et al. 2007; Mehdi et al. 2007; Sangaré et al. 2016). A very significant accumulation of MTE was noted in the station of Sidi Haider (station that shelters an automobile breakage), this accumulation is the consequence of contamination by the products of decomposition of this waste materials. Several studies have reported this type of contamination of soil and vegetation by the deposition of particles from automobile wear (Lange et al. 2017; Zanello et al. 2018; Bernardino et al. 2019; Mihankhah et al. 2020).

The high $\mathrm{Cu}$ level in the Sidi Haider station of up to $150 \mathrm{mg} / \mathrm{kg}$ is due to the presence of this auto box; Several studies have proven the relationship between $\mathrm{Cu}$ levels and certain polluting sources (paint, brake pads, tires, and car wiring) (Winther and Slento 2010; Hsu et al. 2018; Barbosa et al. 2020).

Another fact that arises is that the plants having more accumulation properties can be used for removing the heavy metal toxicity in the roadside environment. Therefore, $H$. cheirifolia offers prospects of application of phytoremediation, and can be identified as tolerant to the presence of high concentrations of ETM, may be subject to further studies, particularly to effect elections of bioaccumulating populations.

In conclusion, this study gives evidence for the accumulation of $\mathrm{Pb}, \mathrm{Zn}, \mathrm{Cu}, \mathrm{Fe}, \mathrm{Mn}, \mathrm{Cd}, \mathrm{Ag}, \mathrm{Bi}$, and $\mathrm{Sb}$ in H. cheirifolia aerial parts sampled in the Setif area. It has shown that the sampled stations are heavily polluted by the presence of high levels of MTE. Overall, the results report that $H$. cheirifolia is good bioindicator and can be used in sol pollution-monitoring studies. The most frequent throughout the site, which offers prospects of application of phytoremediation. The results showed that both plants were able to uptake a considerable amount of MTE, indicating that $H$. cheirifolia has potential for elements phytoremediation.

Another fact that arises is that the plants having more accumulation properties can be used for removing the heavy metal toxicity in the roadside environment. Therefore, $H$. cheirifolia offers prospects of application of phytoremediation, and can be identified as tolerant to the presence of high concentrations of MTE, may be subject to further studies, particularly to effect elections of bioaccumulating populations.

\section{ACKNOWLEDGEMENTS}

The source financials for the work are provided by MESRS of Algeria (Project code No. D01N01UN190120200005), and no potential conflicts of interest.

\section{REFERENCES}

Adimalla N, Qian H, Wang H. 2019. Assessment of heavy metal (HM) contamination in agricultural soil lands in northern Telangana, India: an approach of spatial distribution and multivariate statistical analysis. Environ Monit Assess 191 (4): 246. DOI: 10.1007/s10661019-7408-1

Adimalla N, Wang H. 2018. Distribution, contamination, and health risk assessment of heavy metals in surface soils from northern Telangana, India. Arabian J Geosci 11 (21): 684 (1-15). DOI: 10.1007/s12517018-4028-y

Adjiri F, Ramdani M, Lograda T, Chalard P. 2018. Bio Monitoring of Metal Trace Elements by Epiphytic Lichen in the Bordj Bou Arreridj Area, East of Algeria Sch Acad J Biosci. 6 (2): 199-208. DOI: 10.21276/sajb.2018.6.2.12

Akbar KF, Hale WH, Headley AD, Athar M. 2006. Heavy metal contamination of roadside soils of Northern England. Soil Water Res 1 (4): 158-163.

Aksoy A, Sahin U, Duman F. 2000. Robinia pseudoacacia L. as a possible biomonitor of heavy metal pollution in Kayseri. Turk J Bot 24 (5): 279-284.

Atayese MO, Eigbadon AI, Oluwa KA, Adesodun JK. 2010. Heavy metal contamination of amaranthus grown along major highways in Lagos, Nigeria. Afr Crop Sci J 16 (4): 225-235. DOI: 10.4314/acsj.v16i4.54390

Baize D. 2000. Teneurs totales en métaux lourds dans les sols français premiers résultats du programme ASPITET. Courrier de l'Environnement de l'INRA 39: 39-54.

Barbosa JZ, Poggere GC, Teixeira WWR, Motta ACV, Prior SA, Curi N. 2020. Assessing soil contamination in automobile scrap yards by portable X-ray fluorescence spectrometry and magnetic susceptibility. Environ Monit Assess 192 (1): 46. DOI: 10.1007/s10661-019-8025-8

Baziene K, Tetsman I, Albrektiene R. 2020. Level of Pollution on Surrounding Environment from Landfill Aftercare. Intl J Environ Res Public Health 17 (6): 2007 (1-14). DOI: 10.3390/ijerph17062007.

Ben Ghaya A, Hamrouni L, Mastouri Y, Hanana M, Charles G. 2013. Impacts of toxic metals on vegetation of the Djebel Hallouf mine in the area of Sidi Bouaouane in BouSalem Northwestern Tunisia. Geo Eco Trop. 37 (2): 243-254.

Bentum JK, Essumang DK, Tuffuor JK, Agyakum I. 2010. Analysis of heavy metals in roadside soils and crops along the Obansandjo way in the Accra metropolis. Intl J Biol Chem Sci. 4 (3): 803-808. DOI: 10.4314/ijbcs.v4i3.60517

Bernardino CA, Mahler CF, Santelli RE, Freire AS, Braz BF, Novo LA. 2019. Metal accumulation in roadside soils of Rio de Janeiro, Brazil: impact of traffic volume, road age, and urbanization level. Environ Monit Assess 191: 156 (1-14). DOI: 10.1007/s10661-019- 7265-y

Bisson M, Bonnomet V, Migne-Fouillen V, Jolibois B, Gay G, Lefcvre JP, Tack K. 2007. INERIS - Fiche de données toxicologiques et environnementales des substances chimiques. Antimoine et ses $\begin{array}{llllll}\text { dérivés. } & \text { Ver. } & 1 & \& & 2, & 54 \mathrm{p} \text {. }\end{array}$ https://substances.ineris.fr/fr/substance/getDocument/2711

Caussy D, Gochfeld M, Gurzau E, Neagu C, Ruedel H. 2003. Lessons from case studies of metals: investigating exposure, bioavailability and risk. Ecotoxicology and environmental safety 56 (1): 45-51. DOI: 10.1016/s0147-6513 (03)00049-6

Cheng S. 2003. Effects of heavy metals on plants and resistance mechanisms. Environ Sci Pollut Res 10 (4): 256-264. DOI: 10.1065/espr2002.11.141.2

Connelly NG, Damhus T, Hartshorn RM, Hutton AT. 2005. Nomenclature of inorganic chemistry. Published for the International Union of Pure and Applied Chemistry (IUPAC). R So Chem2: 373-377.

Djeddi Hamssa, Saliha Kherief, Nacereddine Dounia, Keddari FatimaZohra, Afri-Mehennaoui. 2018. Teneurs Des Éléments Traces Métalliques $\mathrm{Cu}, \mathrm{Zn}$ Et $\mathrm{Pb}$ Des Sédiments Du Barrage Béni Haroun (Nord-Est De l'Algérie). Eur Sci J 14 (15): 269-286. DOI: 10.19044/esj.2018.v14n15p269

Drahota P, Raus K, Rychlíková E, Rohovec J. 2018. Bio accessibility of $\mathrm{As}, \mathrm{Cu}, \mathrm{Pb}$, and $\mathrm{Zn}$ in mine waste, urban soil, and road dust in the historical mining village of Kaňk, Czech Republic. Environ Geochem Health 40 (4): 1495-1512. DOI: 10.1007/s10653-017-9999-1

Dung TTT, Cappuyns V, Swennen R, Phung NK. 2013. from geochemical background determination to pollution assessment of heavy metals in sediments and soils. Rev Environ Sci Biotechnol 12 (4): 335-353. DOI: $10.1007 / \mathrm{s} 11157-013-9315-1$

Francová A, Chrastný V, Šillerová H, Vítková M, Kocourková J, Komárek M. 2017. Evaluating the suitability of different environmental samples for tracing atmospheric pollution in industrial areas. Environ Pollut 220: 286-297. DOI: 10.1016/j.envpol.2016.09.062 
Gardea-Torresdey JL, Peralta-Videab JR, De la Rosa G, Parsons JG. 2005. Phytoremediation of heavy metals and study of the metal coordination by X-ray absorption spectroscopy. Coord. Chem. Rev. 249: 17971810. DOI: 10.1016/j.ccr.2005.01.001

Gav BL, Aremu MO, Usman Y, Tsaviv JN. 2015. Bioaccumulation of trace metals in fishes from selected rivers of Nasarawa state, Nigeria. Intl J Chem Res 5 (3): 1-10.

Gratão PL, Prasad MNV, Cardoso PF, Lea PJ, Azevedo RA. 2005. Phytoremediation: green technology for the cleanup of toxic metals in the environment. Braz J Plant Physiol 17 (1): 53-64. DOI 10.1590/S1677-04202005000100005

Hasanuzzaman M, Nahar K, Fujita M (eds.). 2018. Plants under Metal and Metalloid Stress. Responses, Tolerance and Remediation, Springer, Singapore. DOI: 10.1007/978-981-13-2242-6

Hassan EL Hadi. 2018. Pollution des sols à Proximité des Routes: Impact des Eléments Traces Métalliques (ETM) sur les Sols à Proximité de la Voie de Contournement des Villes de Rabat et Salé (Maroc). Eur J Sci Res 150: 60-72.

Hesami R, Salimi A, Ghaderian SM. 2018. Lead, zinc, and cadmium uptake, accumulation and phytoremediation by plants growing around Tange Douzan lead-zinc mine, Iran. Environ Sci Pollut Res 25 (9): 8701-8714. DOI: 10.1007/s11356-017-1156-y

Hsu DJ, Chung SH, Dong JF, Shih HC, Chang HB, Chien YC. 2018 Water-based automobile paints potentially reduce the exposure of refinish painters to toxic metals. Intl J Environ Res Public Health 15 (5): 899. DOI: 10.3390/ijerph15050899

Julien Dron, Annabelle Austruy, Yannick Agnan, Aude Ratier, Philippe Chamaret. 2016. Biomonitoring with lichens in the industrialoportuary zone of Fos-sur-Mer (France): Feedback on three years of monitoring at a local collectivity scale. Pollution atmosphérique 228 (1): 1-17. DOI: $10.4267 /$ pollution-atmospherique.5392

Kabata-Pendias A, Mukherjee AB. 2007. Trace Elements from Soil to Human. Springer Science and Business Media, Berlin,

Kambhampati MS, Begonia GB, Begonia MFT, Bufford Y. 2003 Phytoremediation of a lead-contaminated soil using Morning Glory (Ipomoea lacunosa L.): effects of a synthetic chelate. Bull Environ Contam Toxicol 71 (2): 379-386. DOI: 10.1007/s00128-003-0175-1

Koné M, Dramane D, Karim Sory T, Ardjouma D, Houenou PV. 2007. Niveaux de contamination des ETM $(\mathrm{Cu}, \mathrm{Zn}, \mathrm{Fe}, \mathrm{Cd}$ et $\mathrm{Pb})$ dans les tissus mous du gastéropode Tympanotonus fuscatus radula collecté dans la lagune Ebrié (Côte d'Ivoire). Eur J Sci Res 18 (4): 628-638. [France]

Krämer U, Chardonnens A. 2001. The use of transgenic plants in the bioremediation of soils contaminated with trace elements. Appl Microbiol Biotechnol 55 (6): 661-672. DOI: 10.1007/s002530100631

Kumar V, Sharma, A., Kaur, P, Singh Sidhu GP, Bali AS, Bhardwaj R, Thukral AK, Cerda A. 2019. Pollution assessment of heavy metals in soils of India and ecological risk assessment: a state-of-the-art. Chemosphere 216: 449-462. DOI 10.1016/j.chemosphere.2018.10.066

Lange CN, Figueiredo AMG, Enzweiler J, Castro L. 2017. Trace element status in the terrain of an impounded vehicle scrapyard. J Radio Anal Nuclear Chem 311 (2): 1323-1332. DOI: 10.1007 /s10967-016-5078-

Lograda T, Harkati Z, Adel K, Ramdani M. 2016. Heavy metals accumulation in species from mine Karzet Youcef (Algeria). Word J Pharmaceut Res 5 (11): 250-260. DOI: 10.20959/wjpr201611-7286

Marrassini C, Peralta I, Anesini C. 2018. Comparative study of the polyphenol content-related anti-inflammatory and antioxidant activities of two Urera aurantiaca specimens from different geographical areas. Chinese Med 13 (1): 22. DOI: 10.1186/s13020018-0181-1

Mehdi M, Djabri L, Hani A, Belabed BE. 2007. Impacts de la décharge de la ville de Tiaret sur la qualité des eaux souterraines. Synthèse (Revue des Sciences et de la Technologie) 16: 64-73. https://www.ajol.info/index.php/srst/article/view/117840

Mihankhah T, Saeedi M, Karbassi A. 2020. A comparative study of elemental pollution and health risk assessment in urban dust of different land-uses in Tehran's urban area. Chemosphere 241: 124984. DOI: 10.1016/j.chemosphere.2019.124984

Mnasri M, Ghabriche R, Fourati E, Zaier H, Sabally K, Barrington S, Lutts S, Abdelly C, Ghnaya T. 2015. Cd and Ni transport and accumulation in the halophyte Sesuvium portulacastrum: implication of organic acids in these processes. Front Plant Sci 6 (156): 1-9. DOI: 10.3389/fpls.2015.00156

Mpundu MMM, Useni SY, Ntumba NF, Muyambo ME, Kapalanga KP, Mwansa M, Ilunga K, Nyembo KL. 2013. Évaluation des teneurs en éléments traces métalliques dans les légumes feuilles vendus dans les différents marchés de la zone minière de Lubumbashi. J Appl Biosci 66: 5106-5113. [France]

Negral L, Suárez-Peña B, Zapico E, Fernández-Nava Y, Megido L, Moreno J, Castrillón L. 2020. Anthropogenic and meteorological influences on PM10 metal/semi-metal concentrations: Implications for human health. Chemosphere 243: 125347. DOI: 10.1016/j.chemosphere.2019.125347

Olukanniand DO, Adebiyi SA. 2012. Assessment of vehicular pollution of roadside soils in Ota Metropolis, Ogun State, Nigeria. Intl J Civil Environ Eng 12 (4): 40-46.

Rollin C, Quiot F. 2006. Eléments traces métalliques - Guide méthodologique: recommandations pour la modélisation des transferts des éléments traces métalliques dans les sols et les eaux souterraines. Rapp. D'étude INERIS. 119p. https://www.ineris.fr/sites/ineris.fr/files/contribution/Documents/6624 -DESP-R01a_.pdf [France]

Rucandio MI, Petit-Domínguez MD, Fidalgo-Hijano C, García-Giménez R. 2011. Biomonitoring of chemical elements in an urban environment using arboreal and bush plant species. Environ Sci Pollut Res 18 (1): 51-63. DOI: 10.1007/s11356-010-0350-y

Saljnikov E, Mrvić V, Čakmak D, Jaramaz D, Perović V, AntićMladenović S, Pavlović P. 2019. Pollution indices and sources appointment of heavy metal pollution of agricultural soils near the thermal power plant. Environ Geochem Health 41: 2265-2279. DOI: 10.1007/s10653-019-00281-y

Sangaré, N, Yao KM, Kwa-Koffi EK, Kouassi NLB, Soro MB, Kouassi AM. 2016. Évaluation de la qualité des ressources en eau près de la décharge urbaine non-contrôlée d'Akouédo par le calcul des risques cancérigènes et des indices de pollution. Afrique Science 12 (5): 279 290.

Simmons RW, Pongsakul P, Chaney RL, Saiyasitpanich D, Klinphoklap S, Nobuntou W. 2003. The relative exclusion of zinc and iron from rice grain in relation to rice grain cadmium as compared to soybean: Implications for human health. Plant Soil 257: 163-170 DOI: 10.1023/A:1026242811667.

Sun L, Guo D, Liu K, Meng H, Zheng Y, Yuan F, Zhu G. 2019. Levels, sources, and spatial distribution of heavy metals in soils from a typical coal industrial city of Tangshan, China. Catena 175: 101-109.

Tighe M, Beidinger H, Knaub C, Sisk M, Peaslee GF, Lieberman M. 2019. Risky bismuth: Distinguishing between lead contaminations sources in soils. Chemosphere 234: 297-301. DOI: 10.1016/j.chemosphere.2019.06.077.

Tossapol L, Najjapak S, Anchana S, Thiranun A, Maleeya K, Prayad P, Choowong A. 2015. Bioaccumulation and biosorption of $\mathrm{Cd} 2+$ and $\mathrm{Zn} 2+$ by bacteria isolated from a zinc mine in Thailand. Ecotoxicol Environ Saf 122: 322-330. DOI: 10.1016/j.ecoenv.2015.08.013

Turer DG, Maynard BJ. 2003. Heavy metal contamination in highway soils: Comparison of Corpus Christi, Texas and Cincinnati, Ohio shows organic matter is key to mobility. Clean Technol Environ Pol 4 (4): 235-245. DOI: 10.1007/s10098-002-0159-6

Winther M, Slento E. 2010. Heavy Metal Emissions for Danish Road Transport. National Environmental Research Institute, Aarhus University, Denmark - NERI Technical Report no. 780, 99p. http://www.dmu.dk/Pub/FR780.pdf.

Wu Z, Chen Y, Han Y, Ke T, Liu Y. 2020. Identifying the influencing factors controlling the spatial variation of heavy metals in suburban soil using spatial regression models. Sci Total Environ 717: 137212. DOI: 10.1016/j.scitotenv.2020.137212.

Zanello S, Melo VF, Nagata N. 2018. Study of different environmental matrices to access the extension of metal contamination along highways. Environmental Science and Pollution Research 25 (6): 5969-5979. DOI: 10.1007/s11356-017-0908-Z.

Zhang C, Yang Y, Li W, Zhang C, Zhang R, Mei Y, Liao X, Liu Y. 2015. Spatial distribution and ecological risk assessment of trace metals in urban soils in Wuhan, central China. Environ Monit Assess. 187: 556 (1-16). DOI 10.1007/s10661-015-4762- 